\title{
ANALISIS FAKTOR YANG MEMPENGARUHI TEKANAN DARAH KARYAWAN OPERATOR TAMBANG DI TENGGARONG SEBERANG
}

\author{
Theresia Tutik Ismiati \\ Diploma III Keperawatan Sekolah Tinggi Ilmu Kesehatan Dirgahayu \\ J1. Pasundan no. 21, Kelurahan Jawa Kecamatan Samarinda Ulu, Kalimantan Timur \\ e-mail: theresialegowo88@gmail.com
}

\begin{abstract}
ABSTRAK
Hipertensi merupakan salah satu masalah kesehatan yang cukup berbahaya di seluruh dunia karena hipertensi merupakan faktor risiko utama gejala peningkatan tekanan darah yang dapat menyebabkan stroke dan penyakit jantung koroner. Jumlah penyandang hipertensi meningkat setiap tahunnya, diperkirakan pada tahun 2025 akan ada 1,5 Miliar orang yang terkena hipertensi, dan diperkirakkan setiap tahunnya 9,4 juta orang meninggal akibat hipertensi dan komplikasi. Tujuan penelitian ini adalah mengetahui seberapa besar faktor resiko hipertensi yang meliputi usia, obesitas, dan kadar kolesterol total dapat mempengaruhi tekanan darah karyawan operator tambang di Tenggarong Seberang. Penelitian ini adalah penelitian non eksperimen menggunakan desain deskripsi korelasi dengan pendekatan cross sectional. Sampel penelitian ini adalah karyawan tambang yaitu operator HD dan Dozer berjumlah 30 orang, data diambil dari rekam medis medical cek up tahun 2020, dianalisis menggunakan chisquere. Hasil analisis menunjukkan hasil faktor usia, kadar kolesterol dan obesitas berpengaruh terhadap kejadian hipertensi pada karyawan yaitu usia $(p=0,042)$, kadar kolesterol $(p=0,017)$ dan obesitas $(p=0,032)$. Usia atau umur merupakan salah satu faktor resiko terjadinya hipertensi yang tidak dapat diubah.
\end{abstract}

Kata kunci: hipertensi, kolesterol, obesitas.

\section{PENDAHULUAN}

Menurut Data Word Health Organization (WHO) tahun 2015 menunjukkan sekitar 1,13 Miliar orang di dunia menyandang hipertensi, artinya 1 dari 3 orang di dunia terdiagnosa hipertensi. Jumlah penyandang hipertensi terus meningkat setiap tahunnya, diperkirakan pada tahun 2025 akan ada 1,5 Miliar orang yang terkena hipertensi, dan diperkirakkan setiap tahunnya 9,4 juta orang meninggal akibat hipertensi dan komplikasi. Hipertensi merupakan salah satu masalah kesehatan yang cukup berbahaya di seluruh dunia karena hipertensi merupakan faktor risiko utama gejala peningkatan tekanan darah yang kemudian berpengaruh pada organ yang lain , seperti stroke untuk otak atau penyakit jantung koroner untuk pembuluh darah jantung dan otot jantung yang mana pada tahun 2016 penyakit jantung iskemik dan stroke menjadi dua penyebab kematian utama di dunia (Ardiansyah, 2012). Hipertensi juga menjadi penyebab kematian dengan angka $23,7 \%$ dari total 1,7 juta kematian di Indonesia tahun 2016 (Anitasari, 2019) dan laporan profil kesehatan Kaltim 2017 ada sekitar 14\% pasien datang ke puskesmas dengan hipertensi. Bedasarkan Rikesdas (2018) prevalensi hipertensi bedasarkan hasil pengukuran pada penduduk usia 18 tahun sebesar 
$34,1 \%$, tertinggi di kalimantan selatan (44.1\%), sedangkan terendah di papua sebesar $(22,2 \%)$. Hipertensi terjadi pada kelompok umur 31-44 tahun $(31,6 \%)$, umur 45-54 tahun (45,3\%), umur 55-64 tahun $(55,2)$.

Penyebab hipertensi hingga saat ini secara pasti belum dapat diketahui, tetapi gaya hidup berpengaruh besar terhadap kasus ini. Terdapat beberapa faktor yang menjadi risiko terjadinya hipertensi, seperti usia, jenis kelamin, merokok, dan gaya hidup kurang aktivitas yang dapat mengarah ke obesitas. Lebih dari 90\% kasus hipertensi, penyebabnya tidak dapat diidentifikasi. Dewasa muda dan lansia adalah kelompok umur yang paling rentan mengalami hipertensi. Sebagian besar karyawan tambang merupakan kelompok usia dewasa muda yang merupakan kelompok rentan mengalami hipertensi. Kondisi kerja monoton dan tuntutan keselamatan kerja, membuat karyawan harus dalam konsentrasi penuh selama bekerja sehingga berbagai upaya dilakukan seperti merokok atau makan makanan ringan selama bekerja. Kelelahan setelah bekerja membuat karyawan tidak banyak beraktivitas setelah pulang bekerja sehingga memicu BMI meningkat, jumlah obesitas karyawan tiap tahun meningkat, yang dapat mempengaruhi peningkatan tekanan darah karyawan (data rekam medis Klinik Ultra Medika, 2020., data group BMI karyawan 2018). Menurut data riset kesehatan dasar (Riskesdas, 2018) menyebutkan banyak kasus hipertensi di Kutai Kartanegara yang belum ditangani.

\section{METODE}

Penelitian ini adalah penelitian non eksperimen dengan menggunakan desain deskripsi korelasi yaitu penelitian untuk mengetahui hubungan antar variable. Metode pendekatan yang digunakan adalah cross sectional. Subjek penelitian hanya diukur sesaat dan sekali saja dalam satu waktu. Hal ini berarti bahwa pengumpulan data hanya dilakukan satu kali pada masing-masing responden. Data respon didapatkan dari hasil medical check up karyawan pada tahun 2020. Karyawan yang bersedia menjadi responden diberikan inform consent yang berisi persetujuan untuk dijadikan sebagai responden untuk kemudian dilakukan pengumpulan data. Pengambilan sampel dilakukan secara acak sesuai kriteria inklusi sejumlah 30 orang. Data yang diperoleh dianalisis mengunakan uji chisquere.

\section{HASIL}

Hasil analisis data diuraikan sebagai berikut

1. Karakteristik Responden

Tabel 1. Karakteristik Responden

Berdasarkan usia

\begin{tabular}{llll}
\hline No & Usia & $\mathrm{n}$ & $(\%)$ \\
\hline 1. & Adult & 28 & $(93)$ \\
2. & Midle age & 2 & $(7)$ \\
\hline
\end{tabular}

Berdasarkan tabel di atas dapat dilihat bahwa usia responden yang berkisar pada usia adult dan midle age atau dewasa dan dewasa pertengahan yang merupakan usia produktif.

Tabel 2. Karakteristik Responden Berdasarkan Tekanan Darah

\begin{tabular}{llll}
\hline No & Tekanan Darah & $\mathrm{n}$ & $(\%)$ \\
\hline 1. & Normal & 0 & 0 \\
2. & Pre hipertensi & 0 & 0 \\
3. & Hipertensi stadium I & 21 & $(70)$ \\
4. & Hipertensi stadium II & 9 & $(30)$ \\
\hline
\end{tabular}

Berdasarka tabel di atas dapat dilihat bahwa karakteristik responden berdasarkan tekanan darah menunjukkan 21 orang $(70 \%)$ responden masuk dalam kategori hipertensi stadium I dengan rentang tekanan darah sistole 140-159 $\mathrm{mmHg}$ dan tekanan diastole dalam rentang 90-99 $\mathrm{mmHg}$ sedangkan sisanya sebanyak 9 responden $(30 \%)$ masuk dalam kategori hipertensi derajat II dengan rentang tekanan darah sistol $\geq 160 \mathrm{mmHg}$ 
dan diastol pada rentang $\geq 100$ mmHg. Hal ini sesuai dengan hasil Riskesdas tahun 2018 dimana hipertensi mulai diserita pada individu usia 31 tahun hal ini dapat terjadi selain karna warisan genetik dari orang tua kepada anaknya, pola hidup dan pola makan tidak sehat nisa memunculkan kecenderungan hipertensi (Kemenkes, 2020).

Tabel 3. Karakteristik Responden

Berdasarkan Kadar Kolesterol Total

\begin{tabular}{llcc}
\hline No & Kadar Kolesterol Total & $\mathrm{n}$ & $(\%)$ \\
\hline 1. & Tinggi $>200 \mathrm{mg} / \mathrm{dl}$ & 30 & 100 \\
2. & Normal $<200 \mathrm{mg} / \mathrm{dl}$ & 0 & 0 \\
\hline
\end{tabular}

Berdasarkan tabel dia atas dapat dilihat bahwa semua responden memiliki kadar kolesterol lebih dari $200 \mathrm{mg} / \mathrm{dl}$. Kolesterol dan hipertensi sangatn berkaitan, salah satu penyebab hipertensi adalah peningkatan kadar kolesterol dalam darah karena peningkatan dan penumpukan kolesterol yang membuat pembuluh darah menyempit. Menyempitnya pembuluh darah akan membuat jantung bekerja lebih keras untuk memompa darah.

Tabel 4. Karakteristik Responden Berdasarkan IMT (Indeks Massa Tubuh)

\begin{tabular}{llcc}
\hline No & IMT & $\mathrm{n}$ & $(\%)$ \\
\hline 1. & Underweight $<18,5$ & 0 & 0 \\
2. Normal 18,5-22,9 & 3 & 10 \\
3. & Overweight 23-24,9 & 0 & 0 \\
4. Obese 1 25-29,9 & 27 & 90 \\
5. Obese II $>30$ & 0 & 0 \\
\hline Berdasarkan table di atas dapat \\
dilihat bahwa karakteristik \\
responden berdasarkan IMT, \\
mayoritas responden masuk dalam \\
kriteria obesitas (90\%). Seseorang \\
dengan obesitas memiliki jaringan \\
lemak berlebih, peningkatan \\
jaringan lemak akan meningkatkan \\
resistensi vaskuler sehingga jantung \\
perlu bekerja lebih keras untuk \\
memompa darah ke seluruh tubuh.
\end{tabular}

\section{Hubungan antar Variabel}

Tabel 5. Hubungan Usia terhadap

Tekanan Darah

\begin{tabular}{llcc}
\hline \multirow{2}{*}{ No } & \multirow{2}{*}{ Usia } & \multicolumn{2}{c}{$\begin{array}{c}\text { Tekanan } \\
\text { Darah }\end{array}$} \\
\cline { 3 - 4 } & & HT I & HT \\
& & \multicolumn{2}{c}{ II } \\
\hline 1. & Adult & 12 & 3 \\
2. & Midle age & 9 & 6
\end{tabular}

Berdasarkan Tabel di atas dapat dilihat bahwa hasil crosstab antara usia dengan tekanan darah didapatkan nilai $\mathrm{p}=0,042$ $(<0,05)$. artinya pada penelitian ini ada hubungan usia dengan tekanan darah. Hasil ini sesuai dengan penelitian sebelumnya yang menyatakan bahwa pada umumnya hipertensi diderita orang orang diatas usia 40 tahun, namun tidak menutup kemungkinan diderita usia muda (Hendrati, 2006).

Tabel 6. Hubungan kolesterol Terhadap

Tekanan Darah

\begin{tabular}{lccc}
\hline \multirow{2}{*}{ No } & \multirow{2}{*}{ Kolesterol } & \multicolumn{2}{c}{ Tekanan } \\
& & \multicolumn{2}{c}{ Darah } \\
\cline { 3 - 4 } & & HT I & HT \\
& & \multicolumn{2}{c}{ II } \\
\hline 1. & Tinggi $>200 \mathrm{mg} / \mathrm{dl}$ & 21 & 9 \\
2. & Normal $<200 \mathrm{mg} / \mathrm{dl}$ & 0 & 0 \\
\hline
\end{tabular}

Berdasarkan tabel di atas dapat dilihat bahwa hasil uji bivariat antara kadar kolesterol dengan tekanan darah didapatkan nilai $\mathrm{p}$ $=0,043 \quad(<0,05)$. artinya pada penelitian ini ada hubungan antara kadar kolesterol dengan tekanan darah.

Tabel 7. Hubungan kolesterol Terhadap

Tekanan Darah

\begin{tabular}{|c|c|c|}
\hline \multirow{2}{*}{ No } & \multirow{2}{*}{ IMT } & $\begin{array}{c}\text { Tekanan } \\
\text { Darah }\end{array}$ \\
\hline & & $\begin{array}{ll}\text { HT I } & \text { HT } \\
& \text { II }\end{array}$ \\
\hline 1. & Normal & 2 \\
\hline 2. & Obesitas & 23 \\
\hline
\end{tabular}

Berdasarkan tabel di atas dapat dilihat bahwa uji bivariat antara obesitas dengan tekanan darah didapatkan nilai $\mathrm{p}=0,050$ $(<0,05)$. artinya pada penelitian 
ini ada hubungan antara obesitas dengan tekanan darah. Obesitas merupakan faktor resiko hipertensi. Hubungan obesitas dengan hipertensi berkaitan dengan indeks massa tubuh. Imdeks massa tubuh sangat berhubungan dengan lemak tubuh. Obesitas meningkatkan kadar kolesterol jahat LDL dan menurunkan kadar koleterol baik HDL.

3. Hubungan Usia, Kolesterol total dan Obesitas yang Paling Berpengaruh Pada Tekanan Darah

Tabel 8. Hubungan usia, kolesterol, IMT Terhadap Tekanan Darah

\begin{tabular}{|c|c|c|c|}
\hline \multirow{2}{*}{ No } & \multirow{2}{*}{ Variabel } & \multicolumn{2}{|c|}{$\begin{array}{c}\text { Tekanan } \\
\text { Darah } \\
\end{array}$} \\
\hline & & $\overline{\text { HT I }}$ & $\begin{array}{l}\mathrm{HT} \\
\text { II }\end{array}$ \\
\hline 1. & Usia & 21 & 9 \\
\hline 2. & Kolesterol & 21 & 9 \\
\hline 3. & Obesitas & 5 & 25 \\
\hline
\end{tabular}
didapatkan hasil bahwa faktor usia, kadar kolesterol dan obesitas berpengaruh terhadap kejadian hipertensi pada karyawan yaitu usia $(p=0,042)$, kadar kolesterol $(p=0,017)$ dan obesitas $(p=0,032)$. Usia atau umur merupakan salah satu faktor resiko terjadinya hipertensi yang tidak dapat diubah. Riskesdas mencatat hipertensi makin berpotensi menyerang seseorang diusia $>55$ tahun namun tidak menutup kemungkinan menyerang juga pada kelompok usia dibawah 40 tahun terutama tekanan sistolik karena keelastisan arteri menurun. Begitupun kadar kolesterol dalam darah yang mengendap pada pembuluh darah akan menghambat aliran darah dan pembuluh darah menjadi sempit dan kaku begitupun lemah yang mengendap lama.

\section{PEMBAHASAN}

Usia responden pada penelitian ini berada pada rentang usia adult (dewasa). Usia produktif ini masalah kesehatan yang bisa menghampiri sangat beragam mulai dari kenaikan berat badan (obesitas) hingga tekanan darah tinggi. Penelitian in.i mengambil sampel karyawan tambang yang bekerja sebagai operator di Tenggarong Seberang. Sebagian besar responden mengalami obesitas, kadar kolesterol di atas normal dan menderita hipertensi. Hasil analisa data menunjukkan terdapat hubungan antara usia, kadar kolesterol total dan obesitas terhadap tekanan darah karyawan tambang salah satu perusahaan tambang di Tenggarong Seberang. Hasil penelitian ini diharapkan dapat menjadi gambaran untuk dapat melakukan pencegahan munculnya faktor resiko terutama peningkatan kadar kolesterol dan obesitas yang dapat menyebabkan terjadinya hipertensi pada karyawan tambang.

\section{KESIMPULAN DAN SARAN Kesimpulan}

Setelah dilakukan pembahasan terkait dengan hasil penelitian, maka kesimpulan yang dapat diambil pada penelitian ini adalah usia merupakan variabel yang bukan menjadi faktor resiko kejadian hipertensi pada karyawan operator di salah satu perusahaan tambang di Kutai Kartanegara. Kadar kolesterol merupakan variabel yang menjadi faktor resiko terjadinya hipertensi pada karyawan operator di salah satu perusahaan tambang di Kutai Kartanegara. Obesitas merupakan variabel yang menjadi faktor resiko terjadinya hipertensi pada karyawan operator di salah satu perusahaan tambang di Kutai Kartanegara. 


\section{Saran}

Saran yang diberikan terkait dengan hasil dan pembahasan dalam penelitian ini adalah bagi penelitian berikutnya diharapkan dapat meneliti dengan faktor resiko lebih banyak dan jumlah sampel lebih banyak dan melakuakn penelitian dengan beberapa tempat berbeda pada satu waktu, variabel independen ditambahkan dalam penelitian.

\section{DAFTAR PUSTAKA}

Ardiansyah, M. (2012). Medikal Bedah. Yogyakarta: Diva Press.

Budiono. (2016). Konsep dasar keperawatan. Jakarta: Kementerian Kesehatan Republik Indonesia.

Debora, O. (2012). Proses keperawatan dan pemeriksaan fisik. Jakarta: Salemba Medika.

Devi, A. K. (2017). Anatomi Fisiologi \& Biokimia Keperawatan. Yogyakarta: PUSTAKA BARU PRESS.

Fikriana, R. (2018). Sistem Kardiovaskuler. Yogyakarta: Deepublish.

Hermanto, R., Isro'in, L., \& Nurhidayat, S. (2020). Upaya Penurunan Nyeri Pada Pasien. Health Sciences Journal, 90-111.

Kalim, H. (2017). Sistem Kardiovaskular. Singapura: Elsevier.

Mubarak, W. I. (2015). Standar Asuhan Keperawatan dan Prosedur Tetap dalam Praktik Keperawatan: Konsep dan Aplikasi dalam Praktik Klinik. Jakarta: Salemba Medika.

Mulyani, S. S. (2019). Asuhan Keperawatan Lansia dengan Hipertensi di Panti Tresna Werdha Nirwana Puri Samarinda. Karya Tulis Ilmiah.

Nurhidayat, S. (2015). Asuhan Keperawatan Pada Hipertensi. Ponorogo: UNMUH Ponorogo Press.
Perki, P. (2015). Pedoman Tatalaksana Hipertensi Pada Penyakit Kardiovaskuler. Jakarta: National Cardiovascular Centre Harapan Kita Hospital.

Udjianti, W. J. (2013). Keperawatan Kardiovaskuler. Jakarta: Salemba Medika. 